\title{
Influence of Static Low Electromagnetic Field on Copper Corrosion in the Presence of Multispecies Aerobic Bacteria
}

\author{
Xiao-Yang Wei ${ }^{1,2} \cdot$ Masoumeh Moradi ${ }^{1,3} \cdot$ Li-Jing Yang $^{1} \cdot$ Zhen-Lun Song $^{1} \cdot$ Bi-Zhang Zheng ${ }^{1} \cdot$ Zhan-Peng Lu ${ }^{2}$
}

Received: 11 November 2018 / Revised: 11 April 2019 / Published online: 22 May 2019

(C) The Chinese Society for Metals (CSM) and Springer-Verlag GmbH Germany, part of Springer Nature 2019

\begin{abstract}
The effects of low electromagnetic field (EMF) $(B=2 \mathrm{mT})$ on the corrosion of pure copper in the absence and presence of multispecies marine aerobic bacteria were investigated in this work. The results showed that EMF has an inhibitory effect on copper metals and decreases the corrosion rate of copper metals in sterile artificial seawater. However, microbiologically influenced corrosion of $\mathrm{Cu}$ was increased in the presence of electromagnetic field due to its effect on the biofilm morphology and structure. EMF reduced the growth rate of bacteria and decreased bacterial attachment, thereby forming a heterogeneous and non-stable biofilm on the $\mathrm{Cu}$ surface in the presence of EMF. Moreover, the biofilm was dispersed throughout the surface after 7 days, whereas the scattered bacteria were observed on the surface after 10 days. Confocal laser scanning microscopy images showed large and deep pits on the surface in the presence of EMF and confirmed the acceleration of Cu corrosion in the presence of EMF and multispecies bacteria. Furthermore, XPS and FTIR results demonstrated that the corrosion products and metabolic by-products were significantly changed in the presence of EMF.
\end{abstract}

Keywords Electromagnetic field $\cdot$ Multispecies aerobic bacteria $\cdot$ Corrosion $\cdot$ Biofilm

\section{Introduction}

Copper and its alloys are widely used in marine environments as sheathing for ship hulls [1] and for structural marine applications because of their low maintenance cost, long service life, high corrosion resistance, machinability, and high thermal and electrical conductivity [2]. However, copper alloys suffer from microbiologically influenced corrosion (MIC) caused by marine aerobic [3-5] and anaerobic bacteria [6-8]. The adhesion of bacterial biofilm promotes or

Available online at http://link.springer.com/journal/40195

Masoumeh Moradi

masoumeh@nimte.ac.cn

1 Key Laboratory of Marine Materials and Related Technologies, Zhejiang Key Laboratory of Marine Materials and Protective Technologies, Ningbo Institute of Materials Technology and Engineering, Chinese Academy of Sciences, Ningbo 315201, China

2 School of Materials Science and Engineering, Shanghai University, Shanghai 200072, China

3 Corrosion and Protection Division, Shenyang National Laboratory for Materials Science, Northeastern University, Shenyang 110819, China inhibits corrosion of copper and its alloys depending on the synergy of many factors in the culture medium [7]. Furthermore, the resistance of copper and its alloys against MIC has been studied due to their broad spectrum of antimicrobial activity [6].

In sea-related environments, some marine engineering facilities, such as ships, generate electromagnetic fields (EMF) while moving, which affect the physiological activities of bacteria [9-11] and the corrosion of metal alloys [12-16]. EMF can influence the metal corrosion by changing the solution $\mathrm{pH}$, inhibiting mass transfer, and lowering material loss [13]. The corrosion rate of copper is significantly reduced in the presence of magnetic fields [13, 17]. Moreover, the influence of MF on biological systems has been widely studied. However, the results of these studies are highly heterogeneous regarding the different strengths of MF and the types of fields (static or time varying) applied. The amount of bacteria and their viability decreases at prolonged exposure times, thereby increasing the temperature and magnetic field intensities [18-20]. The biofilm formation and the growth rate of bacteria $[18,19]$ and other microorganisms, such as yeast [21], can be influenced by a low level of EMF. Sometimes, MF can increase the influence of antimicrobial agents [22]. Recently, the application of low-frequency EMF 
has attracted much interest for the prevention or removal of bacterial biofilm formation [9, 18]. This method is predicted to be widely used for controlling biofilm pathogens [11]. A low MF (2-4 mT) could reduce the MIC of 304 stainless steel by controlling the sulphate-reducing bacteria (SRB) activity [23] and delaying the biofilm formation on the metal surfaces. Moreover, magnetic fields influence ferrous alloys, whereas relatively few reports have been published regarding the effect of EMF on non-ferromagnetic metals in solutions with non-paramagnetic ions. Furthermore, the effects of EMF and multispecies aerobic bacteria on the corrosion of pure copper have not been reported and thus need to be studied due to their numerous applications in marine environment.

This work investigates the influence of low EMF on the corrosion behaviour of pure copper in the presence of multispecies aerobic bacteria isolated from East China Sea, Ningbo, during autumn. Different electrochemical and surface analysis techniques were used to study the process of biofilm formation and investigate the mechanism of copper corrosion.

\section{Materials and Methods}

A square-shaped pure copper with a diameter of $10 \mathrm{~mm}$ and thickness of $2 \mathrm{~mm}$ was used in this work. Four aerobic bacteria, namely Vibrio alginolyticus, Acinetobacter venetianus, Vibrio fluvialis, and Jeotgalibacillus alkaliphilus, were isolated from East China Sea, Ningbo, China (GPS $29^{\circ} 59^{\prime} 50.59^{\prime \prime} \mathrm{N}, 122^{\circ} 2^{\prime} 34.99^{\prime \prime} \mathrm{E}$ ), and identified and confirmed by $16 \mathrm{~S}$ rRNA gene as described in a previous work [24]. The artificial seawater used in this study was composed of (per litre): $23.476 \mathrm{~g} \mathrm{NaCl}, 1.469 \mathrm{~g} \mathrm{CaCl}_{2} \cdot 6 \mathrm{H}_{2} \mathrm{O}, 0.192 \mathrm{~g}$ $\mathrm{NaHCO}_{3}, 10.61 \mathrm{~g} \mathrm{MgCl}_{2} \cdot 6 \mathrm{H}_{2} \mathrm{O}, 3.917 \mathrm{~g} \mathrm{Na}_{2} \mathrm{SO}_{4}, 0.026 \mathrm{~g}$ boric acid, $0.667 \mathrm{~g} \mathrm{KCl}$, and $0.096 \mathrm{~g} \mathrm{KBr}$. A total of $3 \mathrm{~g} / \mathrm{L}$ peptone was added to this medium to providing nutrients for the bacteria. The $\mathrm{pH}$ was adjusted to 7.6 by using a saturated
$\mathrm{NaOH}$ solution and sterilised by autoclaving at $120^{\circ} \mathrm{C}$ for $30 \mathrm{~min}$. Figure 1 shows the schematic of a flat-plate bioreactor used. The details of bioreactor size and condition can be found elsewhere [25]. Magnetic fields were generated using a cylindrical coil connected to a DC galvanostatic power source. The maximum effective current was $1.9 \mathrm{~A}$ which corresponded to the amplitude of magnetic induction, $B_{\mathrm{m}}=2$ $\mathrm{mT}$. The temperature was controlled at $30^{\circ} \mathrm{C}$ by circulating hot water, and the flow rate was regulated by using a peristaltic pump at $100 \mathrm{rpm}$.

Electrochemical measurements were performed in a three-electrode system containing a copper sample as a working electrode, a platinum sheet as an auxiliary electrode, and saturated calomel electrode (SCE) as a reference electrode. All electrochemical measurements were carried out by using an AUTOLAB PGSTAT302 (Metrohm AG, Switzerland) potentiostat-galvanostat. Electrochemical impedance spectroscopy (EIS) was performed after $30 \mathrm{~min}$ of $E_{\mathrm{OCP}}$ measurements to obtain a steady-state condition over a frequency range of $100-10 \mathrm{mHz}$ with a $10-\mathrm{mV}$ sinusoidal signal. The potentiodynamic polarisation was carried out from a cathodic potential of $-500 \mathrm{mV}$ to an anodic potential of $+500 \mathrm{mV}$ with respect to $E_{\mathrm{OCP}}$ against SCE with a scan rate of $1 \mathrm{mVs}^{-1}$. GPES software was used to collect the data and determine the corrosion potential $\left(E_{\text {corr }}\right)$ and the corrosion current density $\left(I_{\text {corr }}\right)$. FRA and ZsimDemo3.22d were also used for EIS data analysis.

Biofilm formation and corrosion products on copper specimens were characterised through FESEM (FEI Quanta FEG 250) after 10-day exposure of the specimens in sterile artificial seawater that contained multispecies aerobic bacteria in the absence and presence of EMF. The samples were rinsed by distilled water and immersed in $2 \%$ glutaraldehyde for $4 \mathrm{~h}$ to immobilise the biofilm. Afterwards, a series of three ethanol solutions (15 min each): $50 \%, 75 \%$, and 100\%, were applied to dehydrate the samples. To remove the biofilm and observe the possibility of localised attack, copper samples were cleaned by ultrasonication in $95 \%$ ethanol for $10 \mathrm{~min}$.
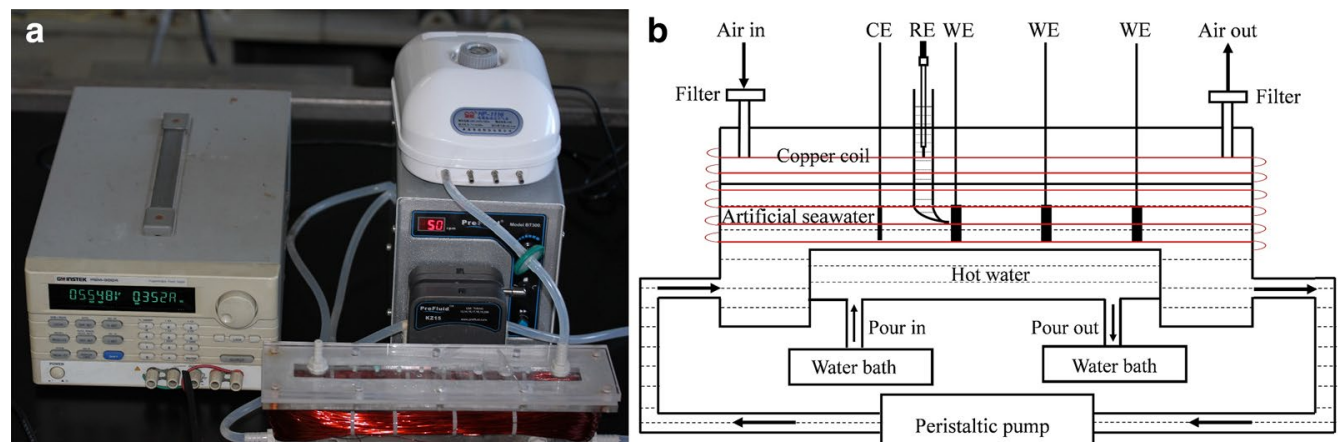

Fig. 1 a Experimental set-up for low EMF with the DC generator, b schematic of flat-plate bioreactor equipped with a solenoid copper used in this study 
The largest pit depth was mapped using confocal laser scanning microscope (CLSM).

To observe the bacterial attachment and biofilm formation, the copper samples were removed from the bioreactor at different times and rinsed with $3 \mathrm{~mL}$ sterile water, immediately followed by staining by using a fluorescent dye (FilmTracerTM LIVE/DEAD ${ }^{\circledR}$ Biofilm Viability Kit, Invitrogen, USA) in darkness for 15-20 min according to the manufacturers' procedure. Images of the stained samples were obtained using a confocal inverted microscope (Leica TCS SP5, Germany).

To study the biofilm features, the copper samples were exposed to sterile artificial seawater containing multispecies aerobic bacteria for 10 days in the presence and absence of EMF. Afterwards, the samples were air-dried and investigated structurally through microscopic FTIR spectroscopy (Agilent, Cary660 +620, USA). FTIR spectra were recorded from 4000 to $500 \mathrm{~cm}^{-1}$ at a resolution $4 \mathrm{~cm}^{-1}$.

\section{Results and Discussion}

\subsection{Effect of EMF on the Growth Rate of Bacteria}

The bacterial growth rate was determined by measuring the $\mathrm{OD}_{600}$ of the bacterial cultures, which indirectly reflected the number of bacteria in the suspension. The results show that at the first $20 \mathrm{~h}$ of exposure (Fig. 2), the growth rate of multispecies bacteria markedly increased. Afterwards, the growth rate stabilised showing the bacteria reach their stationary phase. At $2 \mathrm{mT}$ EMF, fractions of the bacterial cells were killed, and the surviving cells continued growing [26]. Later, the growth of multispecies bacteria was inhibited

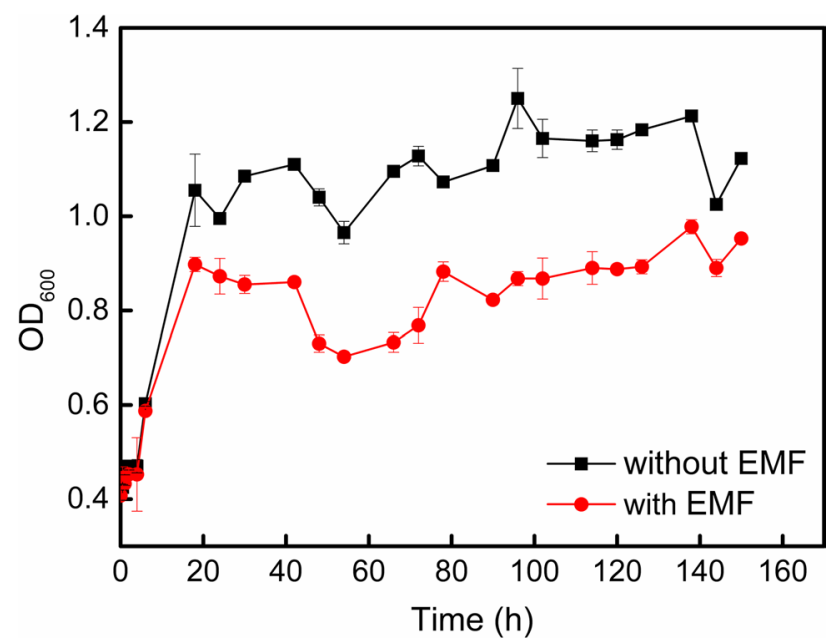

Fig. 2 Variation in growth rate of planktonic bacteria in flat-plate bioreactor without and with EMF during 7 days of exposure at $50 \mathrm{rpm}$ and $30{ }^{\circ} \mathrm{C}$ upon exposure to EMF, especially after $40 \mathrm{~h}$, and reached their lowest value after $52 \mathrm{~h}$. Finally, the growth rate slightly increased and stabilised.

\subsection{Effect of Magnetic Field on the Biofilm Morphology}

Figure 3 shows the CLSM images of $\mathrm{Cu}$ coupons exposed to bacterial solutions in the presence and absence of EMF at different periods. In the absence of EMF, a high number of bacteria attached to the surface after 1 day (Fig. 3a) and the biofilm was formed on the surface after 5 days (Fig. 3b) and displayed a high level of red fluorescence. This finding indicated that the biofilm was formed by mostly dead and inactive bacteria. Biofilms continuously grew up and a dense and homogenous biofilm was formed by multispecies bacteria on the $\mathrm{Cu}$ surfaces after 7 days (Fig. 3c). After 10 days of exposure, the biofilm thickened and became heterogeneous (Fig. 3d).

In the presence of EMF, the number of attached bacteria on the surface significantly decreased (Fig. $3 \mathrm{a}^{\prime}$ ) and the biofilm formed on the surface showed a heterogeneous morphology after 5 days (Fig. 3b'). However, the apparent ratio of live to dead cells increased in the presence of EMF, thus indicating biofilm activity. The EMF accelerated and reached the death phase of the biofilm. Hence, after 7 days (Fig. 3c') the biofilm was almost detached from the surface, and scattered biofilms became visible, with a high proportion of dead cells on the surface. After 10 days (Fig. 3d'), the number of bacteria significantly decreased on the surface, thus confirming the power of EMF in controlling biofilm maturation on $\mathrm{Cu}$ surfaces. EMF halted the biofilm formation [18]. Conversely, we found that EMF decreased bacterial attachment on the surface and caused biofilm disruption after several days.

The biofilm composition was analysed through FTIR spectroscopy. The FTIR spectra of the biofilm formed on the metal surface are shown in Fig. 4. The intensities of the resulting bonds decreased significantly in the presence of EMF. In both systems, a strong and broad absorption peaks at the range of $3320-3340 \mathrm{~cm}^{-1}$ were ascribed to the stretching vibrations of $\mathrm{O}-\mathrm{H}$ and $\mathrm{N}-\mathrm{H}$ as characteristics of water molecules and proteins [27]. The peaks at $2962 \mathrm{~cm}^{-1}$ and $2920 \mathrm{~cm}^{-1}$ were ascribed to the stretching vibration of $\mathrm{CH}_{2}$ and $\mathrm{CH}_{3}$, respectively [28], indicating the presence of fatty acids in the biofilm structure. In the absence of EMF, a strong absorption peak was observed at $1641 \mathrm{~cm}^{-1}$, which was attributed to the $\mathrm{C}=\mathrm{O}$ (amide $\mathrm{I}$ ) stretching vibrations of the peptide bond as the functional group of proteins. The intensity of this peak was significantly decreased in the presence of EMF. The peak at $\sim 1548 \mathrm{~cm}^{-1}$ demonstrated the $\mathrm{N}-\mathrm{H}$ bending vibration/C-N stretching vibration of the amide II structures in the biofilm. This peak disappeared in the presence of EMF, and another peak at $1457 \mathrm{~cm}^{-1}$ was observed and assigned to the protein side chain $\mathrm{COO}^{-}$. The 

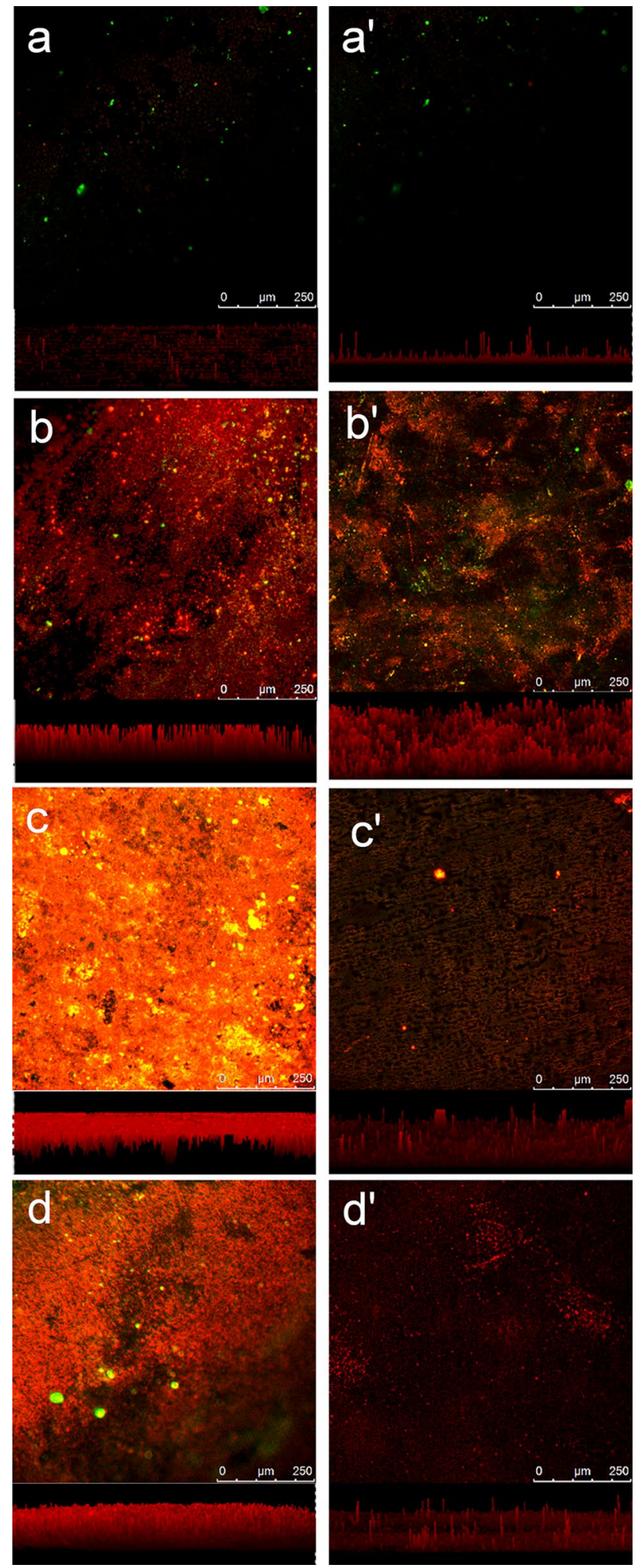

Fig. 3 CLSM images of pure $\mathrm{Cu}$ exposed to artificial seawater inoculated with multispecies aerobic bacteria for 1 days $\mathbf{a}, \mathbf{a}^{\prime}, 5$ days $\mathbf{b}$, $\mathbf{b}^{\prime}, 7$ days $\mathbf{c}, \mathbf{c}^{\prime}$ and 10 days $\mathbf{d}, \mathbf{d}^{\prime}$ without $\mathbf{a}-\mathbf{d}$, with EMF $\mathbf{a}^{\prime}-\mathbf{d}^{\prime}$ with $50 \mathrm{rpm}$ and $30{ }^{\circ} \mathrm{C}$

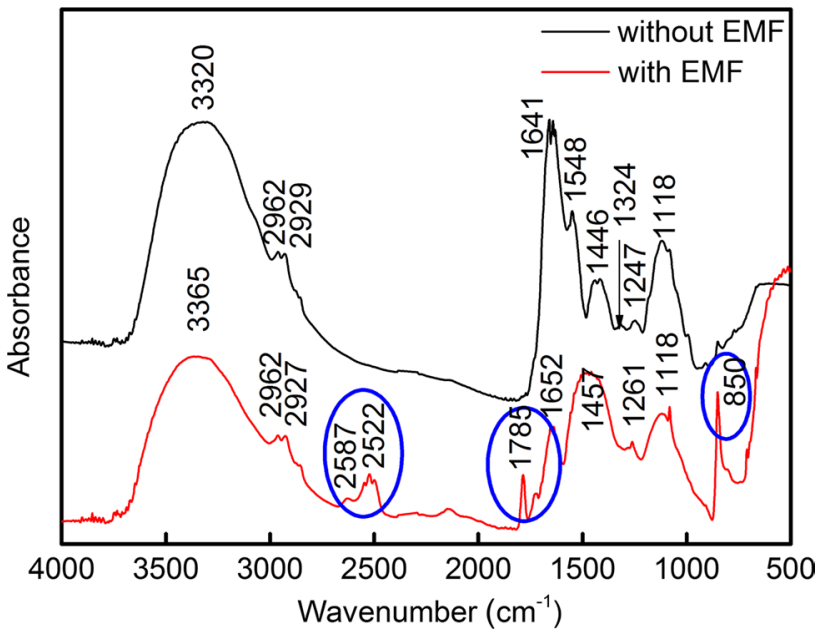

Fig. 4 FTIR spectra of biofilm formed on pure $\mathrm{Cu}$ specimens exposed to sterile artificial seawater inoculated with multispecies aerobic bacteria without and with EMF for 10 days at $50 \mathrm{rpm}$ and $30^{\circ} \mathrm{C}$

peaks at $1247 \mathrm{~cm}^{-1}$ and $1261 \mathrm{~cm}^{-1}$ were assigned to the $\mathrm{C}-\mathrm{N}$ stretching vibration/ $\mathrm{N}-\mathrm{H}$ bending vibration [29], thus indicating the presence of amide III band in the protein structure. The peaks at $1118 \mathrm{~cm}^{-1}$ were associated with the $\mathrm{C}-\mathrm{O}$ stretching vibrations due to the presence of carbohydrates.

After the introduction of EMF, the following peaks appeared:

- a peak at $1780 \mathrm{~cm}^{-1}$ related to the $\mathrm{C}=\mathrm{O}$ stretching of esters [30];

- small peaks at $2587 \mathrm{~cm}^{-1}$ and $2522 \mathrm{~cm}^{-1}$, which were related to $\mathrm{OH}$ stretching due to the presence of amino acid (as a constituent protein); and

- a peak at $850 \mathrm{~cm}^{-1}$ was ascribed to phosphate functional groups and stretching vibration of metal-O-P [6, 31].

The FTIR results showed that the biofilm structure was composed of lipids, proteins and carbohydrates in both systems. However, the protein structure significantly changed upon introduction of EMF, and the majority of protein in the control solution was composed of amide II structure. In the presence of EMF, different amide structures (amide I, II and III) showed equivalent contribution in protein composition.

\subsection{Effect of EMF and Multispecies Bacteria on the Corrosion Process of $\mathrm{Cu}$}

\subsubsection{Electrochemical Results}

EIS spectra were obtained under stable OCP for different exposure times in four different conditions, that is, in the presence and absence of EMF in sterile artificial seawater and in the presence of multispecies bacteria. 

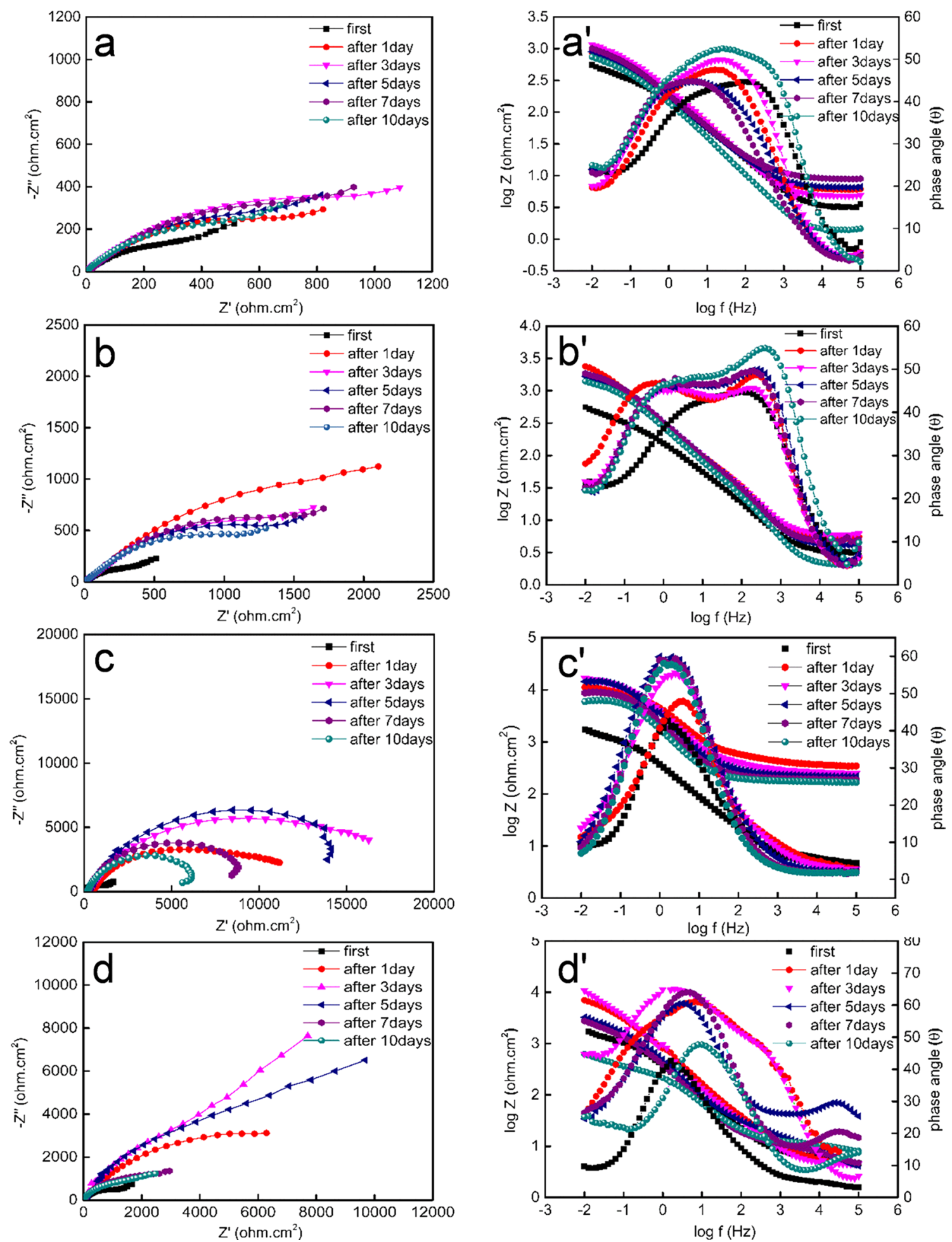

Fig. 5 Nyquist plots a-d and Bode diagrams $\mathbf{a}^{\prime}-\mathbf{d}^{\prime}$ obtained for pure $\mathrm{Cu}$ specimens exposed to sterile artificial seawater $\mathbf{a}, \mathbf{a}^{\prime}, \mathbf{b}, \mathbf{b}^{\prime}$ and inoculated medium with multispecies marine aerobic bacteria $\mathbf{c}, \mathbf{c}^{\prime}, \mathbf{d}, \mathbf{d}^{\prime}$ in the absence $\mathbf{a}, \mathbf{a}^{\prime}, \mathbf{c}, \mathbf{c}^{\prime}$, presence of EMF $\mathbf{b}, \mathbf{b}^{\prime}, \mathbf{d}, \mathbf{d}^{\prime}$ at different immersion times at $50 \mathrm{rpm}$ and $30^{\circ} \mathrm{C}$

Time-dependent Nyquist plots exposed to different conditions are shown in Fig. 5a-d, and the corresponding Bode plots are displayed in Fig. $5 \mathrm{a}^{\prime}-\mathrm{d}^{\prime}$.
Impedance value decreased with exposure time under all conditions and reached its lowest value after 10 days. However, the trend was considerably changed in the presence 
of EMF. In sterile artificial seawater, the diameter of the semicircle increased as exposure time increased to 3 days due to the formation and thickening of the oxide layer [32]. At low frequency, a straight line became evident and was associated with the diffusion of soluble copper species from the electrode surface to the bulk solution [33]. When EMF was introduced to sterile artificial seawater, the diameters of capacitive loops increased after 1 day and then decreased with exposure time, indicating the rapid formation of the oxide layer on $\mathrm{Cu}$ surfaces. The $\mathrm{Cl}^{-}$ion probably diffused into the oxide layer and weakened this layer [24].

In the presence of multispecies bacteria with and without EMF, the impedance value increased significantly due to the formation of the biofilm on the surface (Fig. 5c, d); however, the inhibitory effect of biofilm was reduced with exposure time. In the presence of EMF, the diameter of the semicircle increased as exposure time increased to 3 days, thereby confirming the biofilm formation on the surface. Afterwards, the semicircle diameter markedly decreased and reached its lowest value after 10 days of exposure. Notably, the maximum phase angle in all systems increased with exposure time, indicating the thickening of the oxide layer. However, the oxide layers did not inhibit $\mathrm{Cu}$ corrosion.

The results of EIS were analysed using ZsimDemo $3.22 \mathrm{~d}$ and are given in Table 1. The quality of fitting was assessed using Chi-square values, which were lower than $1.2 \times 10^{-3}$, thus indicating acceptable fitting results [33]. Figure 6 shows the electrochemical equivalent circuit modelling that explains the corrosion behaviour of $\mathrm{Cu}$ in the sterile solution and in the presence of multispecies aerobic

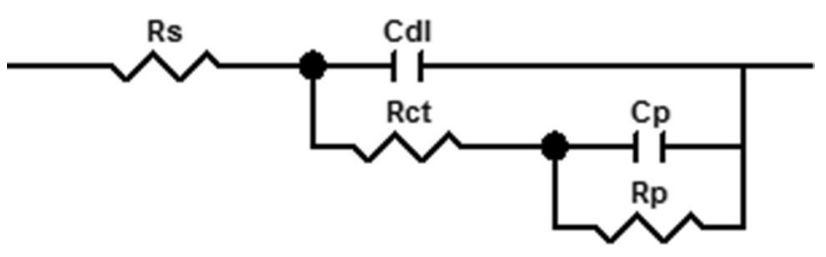

Fig. 6 Equivalent circuit model for the evaluation of the experimental impedance diagrams of pure $\mathrm{Cu}$ in the sterile artificial seawater and in the presence of multispecies marine aerobic bacteria without and with EMF
Table 1 Electrical elements obtained from the best fitting of experimental impedance diagrams of the pure $\mathrm{Cu}$ / electrolyte interface, using Zsim program

\begin{tabular}{|c|c|c|c|c|c|c|c|}
\hline Sample & $R_{\mathrm{s}}\left(\Omega \mathrm{cm}^{2}\right)$ & $R_{\mathrm{ct}}\left(\Omega \mathrm{cm}^{2}\right)$ & $\mathrm{CPE}_{\mathrm{dl}}\left(\mathrm{mF} \mathrm{cm}^{-2}\right)$ & $n$ & $R_{\mathrm{f}}\left(\Omega \mathrm{cm}^{2}\right)$ & $\mathrm{CPE}_{\mathrm{p}}\left(\mathrm{mF} \mathrm{cm}^{-2}\right)$ & $n$ \\
\hline \multicolumn{8}{|c|}{ In sterile artificial seawater } \\
\hline First & 3.05 & 1137 & 0.392 & 0.73 & 2.63 & 9.55 & 0.36 \\
\hline After 1 day & 5.12 & 1286 & 0.405 & 0.73 & 1.07 & 1.29 & 0.43 \\
\hline After 3 days & 4.72 & 1661 & 1.25 & 0.8 & 39.95 & 0.347 & 0.78 \\
\hline After 5 days & 6.37 & 1367 & 1.58 & 0.47 & 20.01 & 0.554 & 0.71 \\
\hline After 7 days & 8.45 & 1298 & 1.71 & 0.58 & 11.79 & 0.51 & 0.89 \\
\hline After 10 days & 1.27 & 1070 & 2.26 & 0.8 & 4.14 & 0.161 & 0.69 \\
\hline \multicolumn{8}{|c|}{ In sterile artificial seawater introduced by EMF } \\
\hline First & 3.01 & 14.89 & 0.318 & 0.8 & 14.89 & 2.01 & 0.8 \\
\hline After 1 day & 8.56 & 16.53 & 0.254 & 0.76 & 45.26 & 1.44 & 0.55 \\
\hline After 3 days & 9.48 & 2242 & 0.221 & 0.79 & 42.75 & 1.18 & 0.55 \\
\hline After 5 days & 6.45 & 2707 & 0.197 & 0.7 & 79.99 & 0.904 & 0.8 \\
\hline After 7 days & 6.26 & 2407 & 0.291 & 0.8 & 53.85 & 1.02 & 0.8 \\
\hline After 10 days & 5.18 & 2156 & 0.312 & 0.8 & 29.38 & 1.21 & 0.8 \\
\hline \multicolumn{8}{|c|}{ In the presence of multispecies aerobic bacteria } \\
\hline First & 4.69 & 1909 & 0.756 & 0.65 & - & - & - \\
\hline After 1 day & 10.51 & 19,150 & 0.0544 & 0.6 & 501.1 & 0.00785 & 0.99 \\
\hline After 3 days & 16.7 & 19,020 & 0.0126 & 0.94 & 389 & 0.0543 & 0.63 \\
\hline After 5 days & 7.86 & 17,120 & 0.0633 & 0.72 & 462.5 & 0.00884 & 0.99 \\
\hline After 7 days & 10.25 & 10,610 & 0.0101 & 0.31 & 206.2 & 0.0844 & 0.81 \\
\hline After 10 days & 9.98 & 9845 & 0.0741 & 0.81 & 185.3 & 0.0185 & 0.8 \\
\hline \multicolumn{8}{|c|}{ In the presence of multispecies aerobic bacteria and EMF } \\
\hline First & 1.86 & 2851 & 0.0256 & 0.99 & 403.1 & 0.190 & 0.52 \\
\hline After 1 day & 4.23 & 9975 & 0.0084 & 0.99 & 273 & 0.359 & 0.66 \\
\hline After 3 days & 4.16 & 16,550 & 0.0175 & 0.98 & 191.6 & 0.326 & 0.7 \\
\hline After 5 days & 5.59 & 12,820 & 0.026 & 0.98 & 243.7 & 0.322 & 0.71 \\
\hline After 7 days & 2.31 & 4596 & 0.205 & 0.98 & 31.42 & 0.42 & 0.52 \\
\hline After 10 days & 2.39 & 4098 & 0.277 & 0.87 & 12.88 & 0.53 & 0.49 \\
\hline
\end{tabular}


bacteria with and without EMF. $R_{\mathrm{s}}$ and $R_{\mathrm{ct}}$ represent the solution resistance and charge transfer resistance, respectively. $R_{\mathrm{f}}$ refers to the resistance of the corrosion product film on the coupon surface for the samples in the sterile solution and stands for the combined resistance of the corrosion products and the bacterial biofilm for the samples in the presence of bacteria [34]. A constant phase element (CPE) was applied in equivalent circuits to replace the capacitance by considering the heterogeneity of the corroded steel specimen. $Z_{\mathrm{Q}}$, the impedance of $Q$, is calculated as follows:

$$
Z_{Q}=Y_{0}-1(j \omega)-\alpha,
$$

where $\omega$ is the angular frequency $(\mathrm{rad} / \mathrm{s})$ and $Y_{0}$ and $\alpha$ are the exponents indicating the deviation of the specimen from an ideal capacitive behaviour [35].

According to the results, EMF had an inhibitory effect against the corrosion of $\mathrm{Cu}$ metal in sterile artificial seawater, whereas $R_{\mathrm{ct}}$ increased from 1070 to $2156 \Omega \mathrm{cm}^{-2}$ after 10 days of exposure in the presence of EMF. However, in artificial seawater containing multispecies aerobic bacteria, EMF inhibited the formation of biofilm on the $\mathrm{Cu}$ surface, and the formed biofilm was dispersed from the surface after 7 days of exposure. Therefore, $R_{\mathrm{ct}}$ decreased to
$4098 \Omega \mathrm{cm}^{-2}$, whereas the $R_{\mathrm{ct}}$ of the $\mathrm{Cu}$ specimens in the presence of multispecies bacteria reached to $9845 \Omega \mathrm{cm}^{-2}$ after 10 days of exposure.

Figure 7 shows the potentiodynamic polarisation curves of $\mathrm{Cu}$ specimens in the presence and absence of EMF in sterile artificial seawater (Fig. 7a) and in the presence of multispecies bacteria (Fig. 7b). The effect of EMF was altered in the presence of bacteria, whereas EMF showed an inhibitory effect in sterile artificial seawater and decreased the corrosion rate of $\mathrm{Cu}$ sample. However, in the presence of bacteria, the corrosion rate considerably increased upon due to the introduction of EMF. Table 2 shows the electrochemical kinetic parameters, including corrosion current density $\left(i_{\text {corr }}\right)$, corrosion potential $\left(E_{\text {corr }}\right)$, anodic Tafel slope $\left(\beta_{\mathrm{a}}\right)$, cathodic Tafel slope $\left(\beta_{\mathrm{c}}\right)$, and corrosion rate $(\mathrm{mm} /$ year). In the presence of bacteria, $i_{\text {corr }}$ significantly decreased and reached its lowest amount $\left(1.74 \mu \mathrm{A} \mathrm{cm}^{-2}\right)$ because of the surface protection by the biofilm and oxide layers. However, EMF destroyed the bacterial biofilm as passive films and increased $i_{\text {corr }}$ to $21.8 \mu \mathrm{A} \mathrm{cm}^{-2}$. The results corroborated with the EIS results.
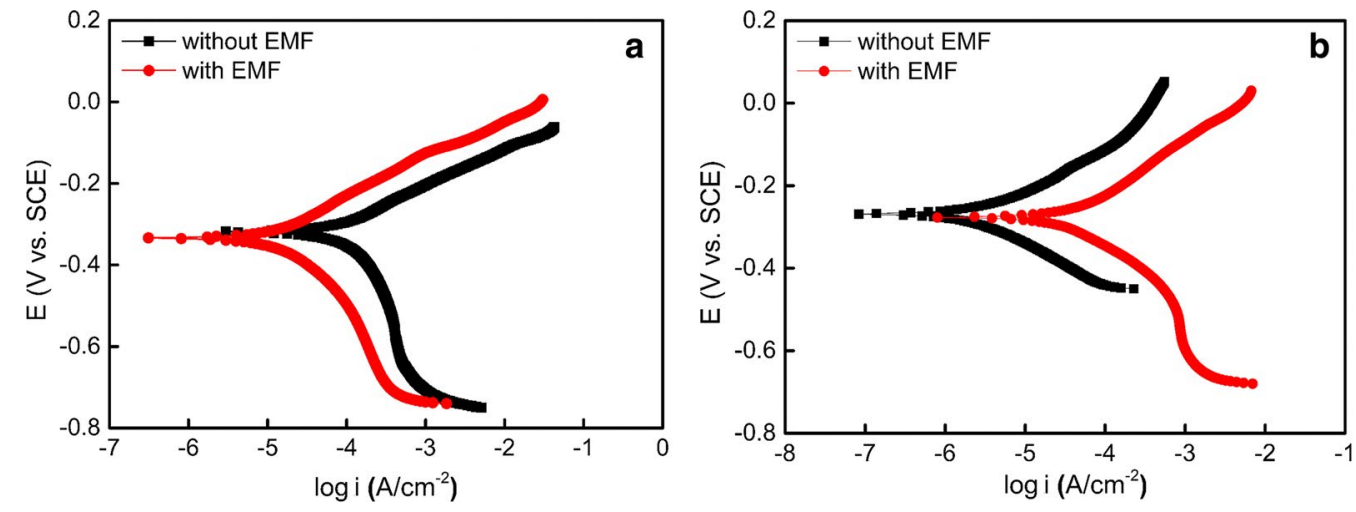

Fig. 7 Tafel polarisation curves of pure $\mathrm{Cu}$ in the sterile artificial seawater $\mathbf{a}$ and in the presence of multispecies marine aerobic bacteria $\mathbf{b}$ without and with EMF for 7 days of exposure at $50 \mathrm{rpm}$ and $30^{\circ} \mathrm{C}$

Table 2 Potentiodynamic polarisation parameters of pure copper metal immersed in the sterile artificial seawater and in the presence of multispecies marine aerobic bacteria in the presence and absence of EMF after 10 days of exposure at $30^{\circ} \mathrm{C}$ and $50 \mathrm{rpm}$

\begin{tabular}{|c|c|c|c|c|c|}
\hline Solution & $E_{\text {corr }}(V$ vs. SCE $)$ & $i_{\text {corr }}\left(\mu \mathrm{A} \mathrm{cm}^{-2}\right)$ & $\beta_{\mathrm{c}}\left(\mathrm{mV} \mathrm{dec}{ }^{-1}\right)$ & $\beta_{\mathrm{a}}\left(\mathrm{mV} \mathrm{dec}{ }^{-1}\right)$ & $\begin{array}{l}\text { Corrosion } \\
\text { rate }(\mathrm{mm} / \\
\text { year })\end{array}$ \\
\hline Sterile artificial seawater without EMF & -0.318 & 67.1 & -103 & 161 & 0.784 \\
\hline Sterile artificial seawater with EMF & -0.269 & 1.74 & -75 & 85 & 0.020 \\
\hline $\begin{array}{l}\text { Artificial seawater containing multispecies } \\
\text { bacteria without EMF }\end{array}$ & -0.334 & 10.05 & -121 & 104 & 0.117 \\
\hline $\begin{array}{l}\text { Artificial seawater containing multispecies } \\
\text { bacteria with EMF }\end{array}$ & -0.277 & 21.8 & -81 & 100 & 0.255 \\
\hline
\end{tabular}




\subsubsection{Surface Analysis}

The biofilm formation and corrosion products on $\mathrm{Cu}$ samples were observed using FESEM. The FESEM images (Fig. 8) revealed a passive film composed of an oxide layer and biofilm covering the $\mathrm{Cu}$ surface (Fig. 8a) after 10 days of exposure in artificial seawater containing multispecies bacteria. When EMF was introduced to this solution, the $\mathrm{Cu}$ surface was corroded and several pits formed on the surface. At some points, bacteria and dispersed biofilm were detected (Fig. 8b'). After removing the corrosion products, intergranular corrosion was observed under both conditions, whereas the whole surface was covered by pits. However, the depth and size of the pits increased in the presence of EMF. The pitting morphology was observed through CLSM. Figure 9 shows small pits covering the whole $\mathrm{Cu}$ surface after exposure to bacterial solution for 10 days. However, deeper pits were observed on the coupons immersed in bacterial solution in the presence of EMF, and the largest pit depth was $6.03 \mu \mathrm{m}$, which was deeper than that of coupons $(4.60 \mu \mathrm{m})$ immersed in bacterial solution without EMF. The pit depth data proved that EMF accelerated the pitting corrosion of $\mathrm{Cu}$ samples in the presence of multispecies bacteria.

\subsection{Surface Characteristics}

To effectively understand the differences in the chemical compositions of the corrosion products, XPS was employed to acquire the $\mathrm{O} 1 \mathrm{~s}, \mathrm{Cu} 2 \mathrm{p}, \mathrm{C} 1 \mathrm{~s}$, and $\mathrm{N}$ 1s spectra of the copper surfaces after 10 days of immersion (Fig. 10). The $\mathrm{O} 1 \mathrm{~s}$ peaks (Fig. 10a) at $530.2 \mathrm{eV}$ and $531.5 \mathrm{eV}$ can be attributed to $\mathrm{Cu}(\mathrm{I})$ in the form of $\mathrm{Cu}_{2} \mathrm{O}$ and $\mathrm{C}-\mathrm{O}$ organic bonding. In the presence of $\mathrm{EMF}$, the $\mathrm{O} 1 \mathrm{~s}$ peaks shifted to higher binding energies (531.8 eV and $532.4 \mathrm{eV}$ ), which was attributed to the presence of $\mathrm{C}-\mathrm{O}$ organic bond and carbonyl bond $(\mathrm{C}=\mathrm{O})[36,37]$.

In the bacterial solution without EMF, the $\mathrm{Cu} 2 \mathrm{p} 3 / 2$ XPS spectrum indicated the presence of $\mathrm{CuO}$ with an intense XPS contribution at $\sim 934 \mathrm{eV}$ accompanied by a medium peak at a binding energy of $942 \mathrm{eV}$. Another peak was observed at $932.2 \mathrm{eV}$, which was attributed to the initial oxidation of copper surface to $\mathrm{Cu}_{2} \mathrm{O}$ during film formation [38]. In the presence of EMF, only two peaks were observed at a binding energy of $\sim 942 \mathrm{eV}$, and these peaks confirmed the presence of $\mathrm{CuO}$ on the surface.

The C 1s spectra (Fig. 10c, c') show the presence of organic compounds on the $\mathrm{Cu}$ surface exposed to bacterial solution in the absence (Fig. 10c) and presence of EMF (Fig. 10c'). The $\mathrm{C} 1 \mathrm{~s}$ spectrum in both solutions has three signals at $284.2 \mathrm{eV}, 285.6 \mathrm{eV}$ and $288.4 \mathrm{eV}$, which were attributed to $\mathrm{C}-\mathrm{C}, \mathrm{C}-\mathrm{N}$ and $\mathrm{C}=\mathrm{O}$, respectively $[39,40]$. Moreover, the $\mathrm{N}$ 1s spectra (Fig. 10d) of the Cu samples incubated in artificial seawater containing multispecies bacteria demonstrated two signals at $399.0 \mathrm{eV}$ and $400.4 \mathrm{eV}$, which were ascribed to functional groups of $=\mathrm{N}-$ and $\mathrm{C}-\mathrm{NH}_{2}$ [41]. In the presence of EMF (Fig. 10d'), the peak at $400.4 \mathrm{eV}$ shifted towards a higher value of $401.1 \mathrm{eV}$, which was associated with the formation of $\mathrm{N}=\mathrm{Cu}$ peak formed via the adsorption of the $\mathrm{N}$-heterocyclic ring coordination with copper [42]. The peak intensity and peak area of $\mathrm{C} 1 \mathrm{~s}$ and $\mathrm{N} 1 \mathrm{~s}$ decreased in the presence of EMF, and these changes were attributed to the low thickness of the biofilm on the copper surface that suppressed the signals of carbon and nitrogen.

\section{Discussion}

Simulated low frequency (up to $1 \mathrm{kHz}$ ) EMF has become an important part of our biosystem in the last century. It can affect microorganisms by changing their metabolism at the molecular level [43]. Magnetic field can decrease the corrosion rate of $\mathrm{Cu}$ alloys in artificial seawater $\left(\mathrm{Cl}^{-}\right.$containing solution) by decreasing the mass transfer rate [45].

In neutral chloride solutions, the main and initial corrosion product of copper is cuprous chloride, $\mathrm{CuCl}$, which is formed via reaction (1)

$\mathrm{Cu}^{+}+\mathrm{Cl}^{-} \rightarrow \mathrm{CuCl}$.

After that, $\mathrm{CuCl}$ reacts to produce cuprous oxide $\left(\mathrm{Cu}_{2} \mathrm{O}\right)$ and then $\mathrm{Cu}_{2} \mathrm{O}$ will be generally oxidised over time to $\mathrm{Cu}(\mathrm{OH})_{2}, \mathrm{Cu}_{2}(\mathrm{OH})_{3} \mathrm{Cl}$, or $\mathrm{CuCO}_{3} \cdot \mathrm{Cu}(\mathrm{OH})_{2}$ in the presence of seawater [44]. In the study, the magnetic field hindered these reactions and decreased the corrosion rate. Hence, the reduced corrosion rate and increased impedance value were observed due to the introduction of EMF into the artificial seawater. However, the corrosion rate of $\mathrm{Cu}$ increased considerably in the presence of artificial seawater containing multispecies bacteria and EMF due to the effect of EMF on bacterial growth and biofilm formation. If a biofilm uniformly covers the surface, the interaction between dissolved oxygen and metal surface is minimised [45]. EMF reduces the biofilm formation on $\mathrm{Cu}$ surfaces and causes direct interaction between the metal and the corrosive environment, and this interaction increases the corrosion rate during the final incubation periods [46]. However, the effect of EMF on the biofilm was observed after 7 days of exposure, thus indicating that EMF accelerated biofilm dispersion. Furthermore, FESEM and CLSM images showed pitting on $\mathrm{Cu}$ surfaces and confirmed the increased corrosion rate of $\mathrm{Cu}$ due to the formation of heterogeneous and non-stable biofilm on the surface. EMF not only caused biofilm differentiation by altering the biofilm morphology, but also affected the biofilm characteristics through the metabolic by-products. The FTIR results showed that the protein structure considerably changed in the presence of EMF. Hence, EMF controls bacterial differentiation and maturation and increased MIC of $\mathrm{Cu}$ in the presence of EMF. 

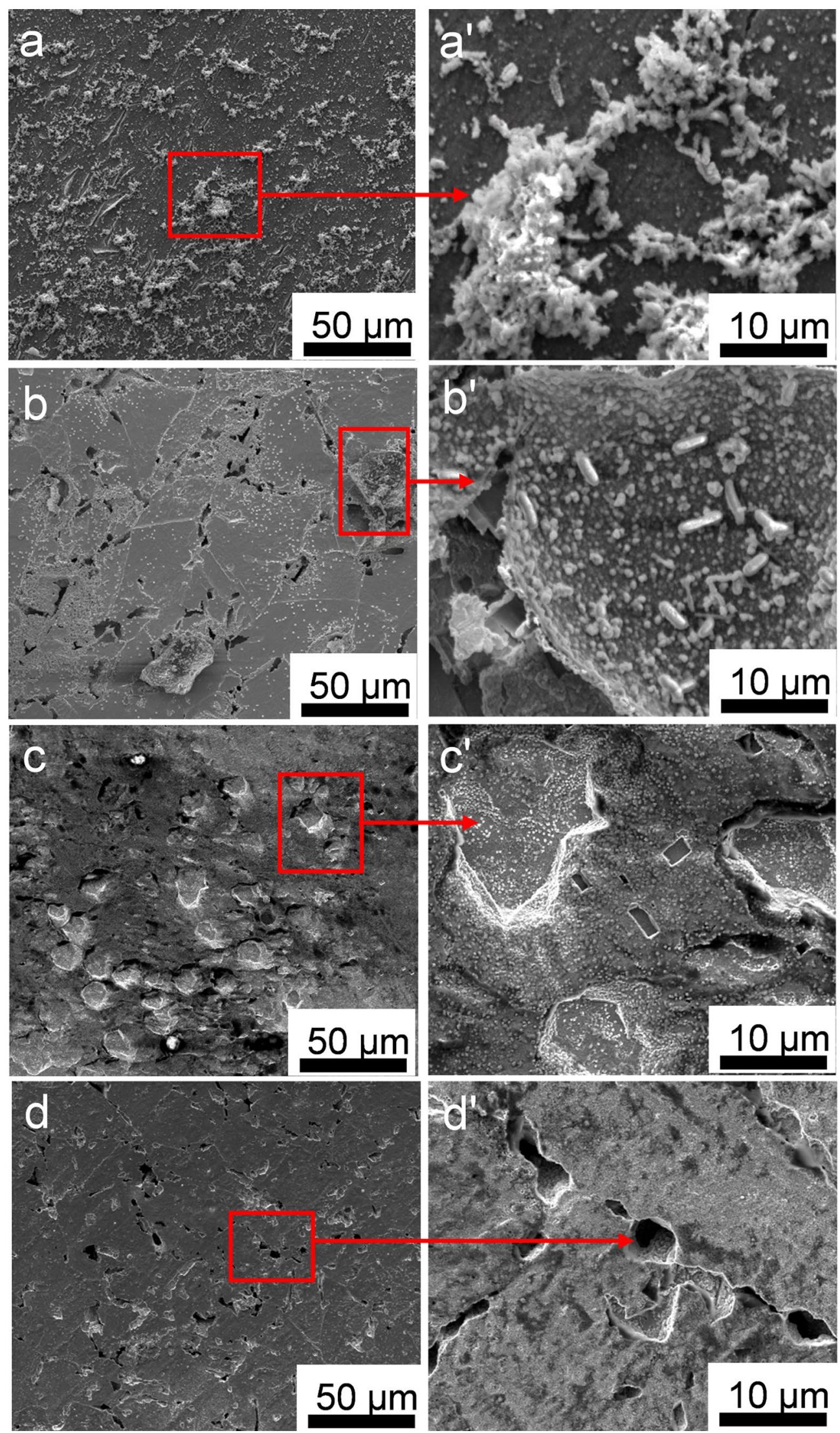

Fig. 8 FESEM images of pure $\mathrm{Cu}$ in the presence of artificial seawater inoculated with multispecies marine aerobic bacteria without $\mathbf{a}, \mathbf{a}^{\prime}, \mathbf{c}, \mathbf{c}^{\prime}$ and with EMF $\mathbf{b}, \mathbf{b}^{\prime}, \mathbf{d}, \mathbf{d}^{\prime}$ before $\mathbf{a}, \mathbf{a}^{\prime}, \mathbf{b}, \mathbf{b}^{\prime}$, after removing biofilm $\mathbf{c}, \mathbf{c}^{\prime}, \mathbf{d}, \mathbf{d}^{\prime}$ 

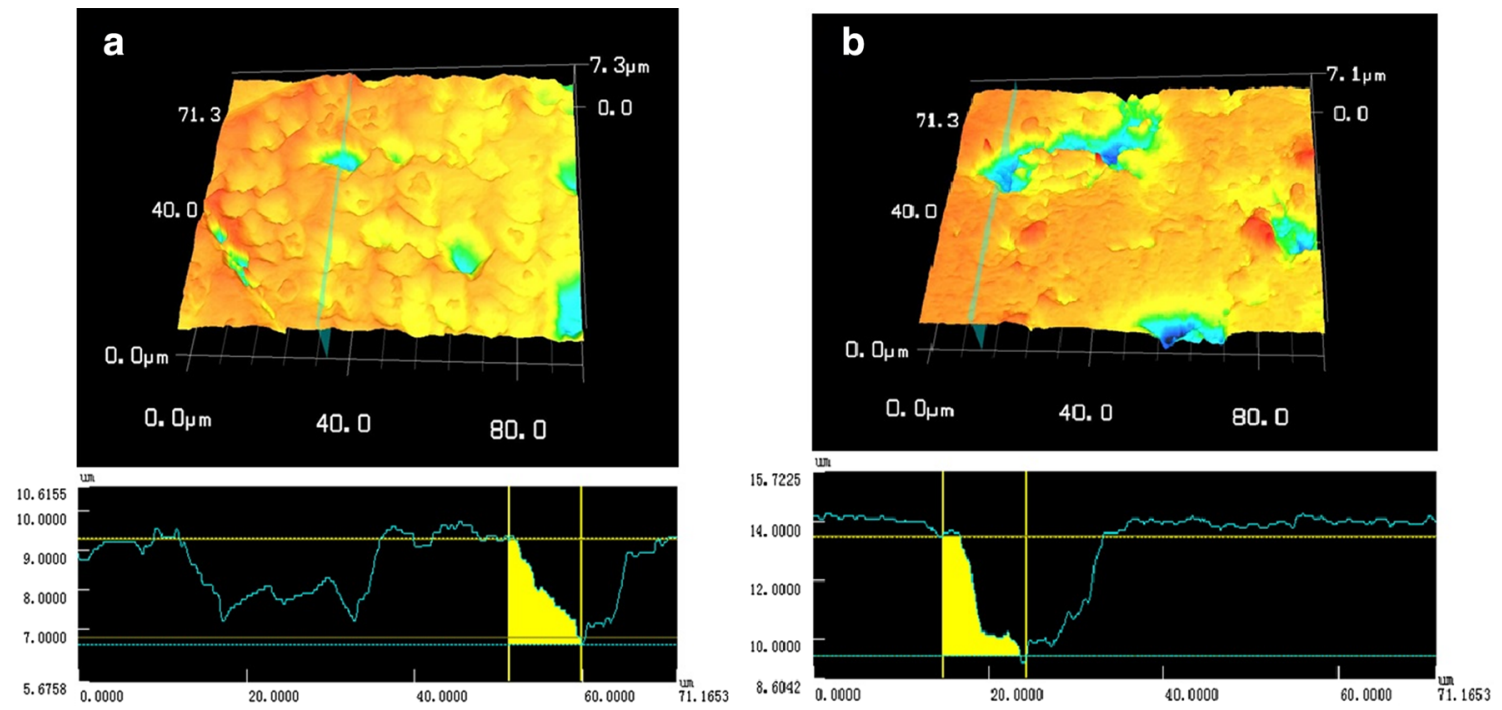

Fig. 9 CLSM analyses of pits on pure $\mathrm{Cu}$ samples exposed to artificial seawater inoculated with multispecies marine aerobic bacteria without a, with EMF b for 10 days at $50 \mathrm{rpm}$ and $30^{\circ} \mathrm{C}$
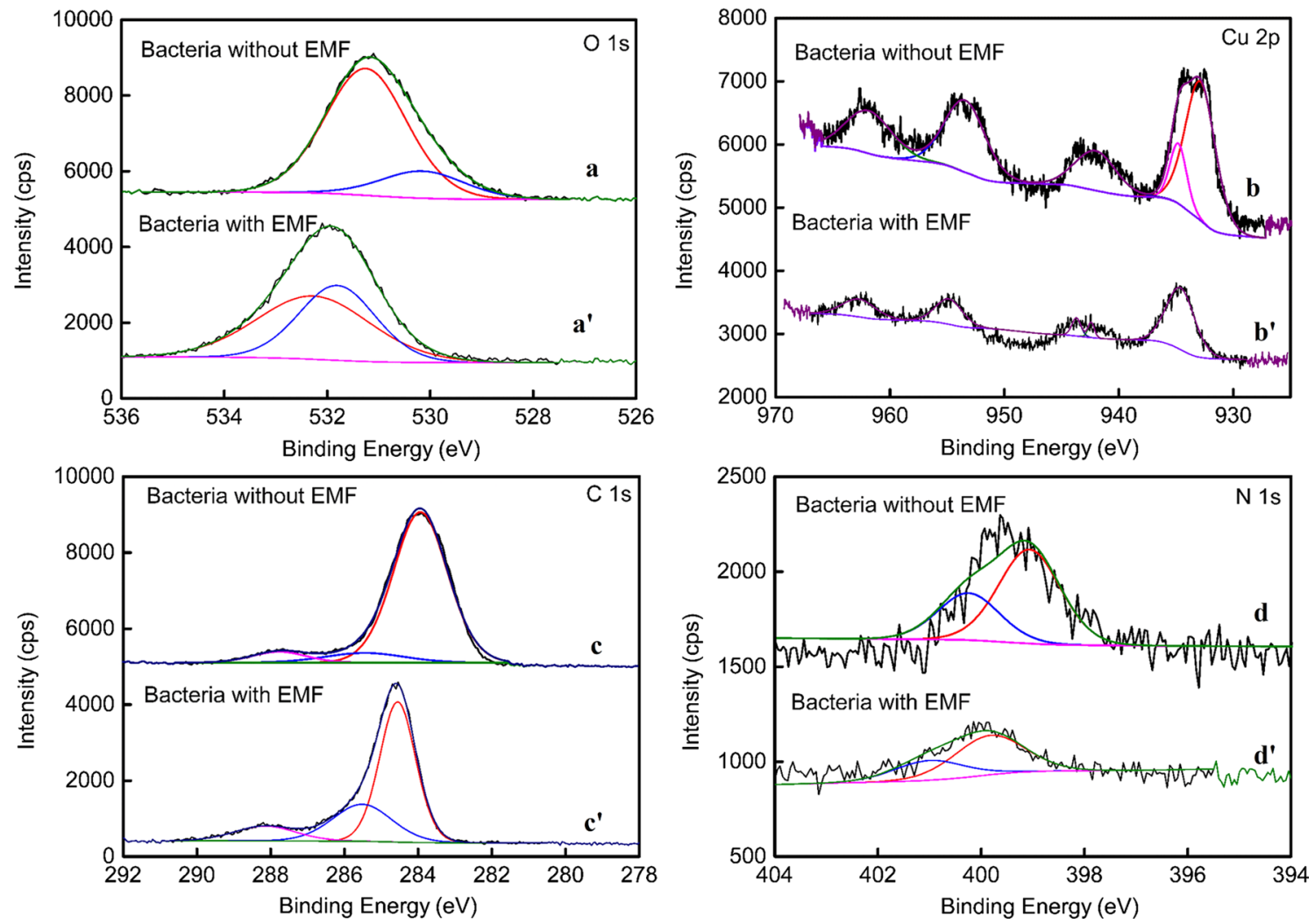

Fig. 10 High-resolution XPS spectra of a, a' $\mathrm{O} 1 \mathrm{~s}, \mathbf{b}, \mathbf{b}^{\prime} \mathrm{Cu} 2 \mathrm{p}, \mathbf{c}, \mathbf{c}^{\prime} \mathrm{C} 1 \mathrm{~s}$, and $\mathbf{d}, \mathbf{d}^{\prime} \mathrm{N} 1 \mathrm{~s}$ for pure Cu samples exposed to artificial seawater inoculated with multispecies marine aerobic bacteria without $\mathbf{a}-\mathbf{d}$, with EMF $\mathbf{a}^{\prime}-\mathbf{d}^{\prime}$ for 10 days at $50 \mathrm{rpm}$ and $30{ }^{\circ} \mathbf{C}$ 


\section{Conclusions}

The corrosion rate of $\mathrm{Cu}$ was suppressed at $2 \mathrm{mT}$ EMF in sterile artificial seawater. However, due to the introduction of EMF into artificial seawater containing multispecies bacteria, the corrosion rate of $\mathrm{Cu}$ decreased due to its influence on biofilm maturation. At $2 \mathrm{mT}$ EMF, the number of bacteria in the solution decreased and their growth slowed down. Furthermore, EMF strongly affected the reduction in bacterial attachment and accelerated the biofilm disruption on copper surfaces. Scattered bacteria were observed on the $\mathrm{Cu}$ surface after 10 days of exposure. Moreover, the metabolic byproducts were significantly changed in the presence of EMF and different protein structures were found on the surface. Hence, despite the inhibitory effect of EMF on Cu corrosion, the MIC considerably increased due to the existence of EMF on $\mathrm{Cu}$ surfaces due to its effect on biofilm maturation.

Acknowledgements This work was supported by National Natural Science Foundation of China (No. 5161101078) and Ningbo 135 Marine Economic Innovation and Development Demonstration Project (No. NBHY-2017-Z2).

\section{References}

[1] D.T. Peters, Review of Copper-Nickel Alloy Sheathing of Ship Hulls and Offshore Structures. The Application of Copper-Nickel Alloys in Marine Systems. Technical report 7044-1919, Greenwich, CT, Copper Development Association (CDA) (1991)

[2] A. Drach, I. Tsukrov, J. DeCew, J. Aufrecht, A. Grohbauer, Corros. Sci. 76, 453 (2013)

[3] E. Huttunen-Saarivirta, P. Rajala, M. Bomberg, L. Carpen, Electrochem. Acta 240, 163 (2017)

[4] N.O. San, H. Nazır, G. Donmez, Corros. Sci. 79, 177 (2014)

[5] N.O. San, H. Nazır, G. Donmez, Corros. Sci. 53, 2216 (2011)

[6] S. Chen, D. Zhang, Corros. Sci. 136, 275 (2018)

[7] S. Chen, P. Wang, D. Zhang, Corros. Sci. 87, 407 (2014)

[8] Y.Y. Song, H.W. Shi, J. Wang, F.C. Liu, Corrosion behavior of cupronickel alloy in simulated seawater in the presence of sulfatereducing bacteria. Acta Metall. Sin. (Engl. Lett.) 30, 1201 (2017)

[9] L. Fojt, L. Strasak, V. Vetterl, Bioelectrochemistry 70, 91 (2007)

[10] A. Obermeier, F.D. Matl, W. Friess, A. Stemberger, Bioelectromagnetics 30, 270 (2009)

[11] G.D. Bonaventura, A. Pompilio, V. Crocetta, S.D. Nicola, F. Barbaro, L. Giuliani, E. D'emilia, E. Fiscarelli, R.G. Bellomo, R. Saggini, Future Microbiol. 9, 1303 (2014)

[12] I. Costa, M.C.L. Oliveira, H.G. de Melo, R.N. Faria, J. Magn. Magn. Mater. 278, 348 (2004)

[13] L.Y. Anga, N.K. Othmana, A. Jalarb, I. Ismail, Proc. Chem. 19, 222 (2016)

[14] Z. Lu, W. Yang, Corros. Sci. 50, 510 (2008)

[15] V.R. Rao, K.V. Bangera, A.C. Hegde, J. Magn. Magn. Mater. 345, $48(2013)$

[16] H.W. Liu, D.K. Xu, B.J. Zheng, A synergistic acceleration of corrosion of Q235 carbon steel between magnetization and extracellular polymeric substances. Acta Metall. Sin. (Engl. Lett.) 31, 456 (2018)
[17] B. Guo, P. Zhang, Y. Jin, S. Cheng, Rare Met. 27, 324 (2008)

[18] T. Karaguler, H. Kahraman, M. Tuter, Biocybern. Biomed. Eng. 37, 336 (2017)

[19] L. Chen, C. Chen, P. Wang, C. Chen, L. Wu, T. Song, J. Magn Magn. Mater. 115, 117 (2018)

[20] L. Fojt, L. Strasak, V. Vetter, J. Smarda, Bioelectrochemistry 63, 337 (2004)

[21] J. Novak, L. Strasak, L. Fojt, I. Slaninova, V. Vetterl, Bioelectrochemistry 70, 115 (2007)

[22] L.O. Mair, A. Nacev, R. Hilaman, P.Y. Stepanov, S. Chowdhury, S. Jafari, J. Hausfeld, A.J. Karlsson, M.F. Shirtliff, B. Shapiro, I.N. Weinberg, J. Magn. Magn. Mater. 427, 81 (2017)

[23] B. Zheng, K. Li, H. Liu, T. Gu, Ind. Eng. Chem. Res. 53, 48 (2014)

[24] M. Moradi, Z. Song, L. Yang, J. Jiang, J. He, Corros. Sci. 84, 103 (2014)

[25] Z. Sun, M. Moradi, Y. Chen, R. Bagheri, P. Guo, L. Yang, Z. Song, C. Xu, Mater. Chem. Phys. 208, 149 (2018)

[26] J. Filipic, B. Kraigher, B. Tepus, V. Kokol, I. Mandic-Mulec, Bioresour. Technol. 120, 225 (2012)

[27] X.B. Peng, Q.A. Li, L.N. Ou, L.F. Jiang, K. Zeng, Int. J. Biol. Macromol. 47, 304 (2010)

[28] S. Zhao, F. Cao, H. Zhang, L. Zhang, F. Zhang, X. Liang, Appl. Biochem. Biotechnol. 172, 2732 (2014)

[29] A.V. Tugarova, P.V. Mamchenkova, Y.A. Dyatlova, A.A. Kamnev, Spectrochim. Acta 192, 458 (2018)

[30] E. Lazzari, T. Schena, M. Caetano, A. Marcelo, C.T. Primaz, A.N. Silva, M.F. Ferrao, T. Bjerk, E.B. Caramao, Ind. Crop. Prod. 111, $856(2018)$

[31] B.M. Lee, H.S. Shin, J. Hur, Chemosphere 90, 237 (2013)

[32] X.N. Liao, F.H. Cao, L.Y. Zheng, W.J. Liu, A.N. Chen, J.Q. Zhang, C.A. Cao, Corros. Sci. 53, 3289 (2011)

[33] S. Hong, W. Chen, H.Q. Luo, N.B. Li, Corros. Sci. 57, 270 (2012)

[34] J. Xu, K. Wang, C. Sun, F. Wang, X. Li, J. Yang, C. Yu, Corros. Sci. 53, 1554 (2011)

[35] S. Chongdar, G. Gunasekaran, P. Kumar, Electrochim. Acta 50, 4655 (2005)

[36] D.Q. Zhang, J.K. Goun, Y.K. Lee, Investigation of molybdatebenzotriazole surface treatment against copper tarnishing. Surf. Interface Anal. 41, 164 (2009)

[37] Y.J. Xu, G. Weinberg, X. Liu, Nanoarchitecturing of activated carbon: facile strategy for chemical functionalization of the surface of activated carbon. Adv. Funct. Mater. 18, 3613 (2008)

[38] O. Akhavan, R. Azimirad, S. Safa, E. Hasani, J. Mater. Chem. 21, 9634 (2011)

[39] J. Landoulsi, M.J. Genet, S. Fleith, Organic adlayer on inorganic materials: XPS analysis selectivity to cope with adventitious contamination. Appl. Surf. Sci. 383, 71 (2016)

[40] E. Vassallo, A. Cremona, F. Ghezzi, Structural and optical properties of amorphous hydrogenated silicon carbonitride films produced by PECVD. Appl. Surf. Sci. 252, 7993 (2006)

[41] B.V. Appa Rao, M. Narsihma Reddy, Arab. J. Chem. 10, S3270 (2017)

[42] C.F. Hao, C. Tai-You, L. Szu-Han, C. Yun-Hsien, C. You-Jyun, L.J. Liang, Surf. Interface Anal. 10, 162 (2018)

[43] R.J.J. Jansen, H. van Bekkum, Carbon 33, 1021 (1995)

[44] G. Kear, B.D. Barker, F.C. Walsh, Corros. Sci. 46, 109 (2004)

[45] L. Strasak, V. Vetterl, J. Smarda, Bioelectrochemistry 55, 161 (2002)

[46] A. Harimawan, H. Devianto, I.C. Kurniawan, J.C. Utomo, Influence of incubation temperature on biofilm formation and corrosion of carbon steel by Serratia marcescens. AIP Conf. Proc. 1805, 060005 (2017) 